\title{
The economic potential of fruit trees as shade in blue mountain coffee agroecosystems of the Yallahs River watershed, Jamaica W.I.
}

\author{
Herlitz Davis • Robert Rice • Larry Rockwood • Thomas Wood • \\ Peter Marra
}

Received: 13 July 2017 / Accepted: 1 November 2017/Published online: 9 November 2017

(C) The Author(s) 2017. This article is an open access publication

\begin{abstract}
Studies in coffee agroecosystems often focus on the conservation and environmental benefits of this managed novel habitat, but rarely examine the socioeconomic benefit of the shade tree products themselves to coffee farmers. An examination of Blue Mountain coffee farmers along an elevation gradient within the Yallahs River watershed saw several tree species emerge as important within the agroecosystems, accounting for approximately $10 \%$ of gross farm incomes. Of the 24 tropical, subtropical or temperate fruit trees reported by farmers, eight species (Mangifera indica, Blighia sapida, two Musa sp.-bananas and plantains, Syzygium samarangense, Persea Americana, and two Citrus sp.- oranges and grapefruits), contributing US $\$ 100$ or greater, accounted for more than $90 \%$ of reported fruit incomes. Our results reveal
\end{abstract}

H. Davis · R. Rice · P. Marra

Smithsonian Migratory Bird Center, National Zoological

Park, Washington, DC 20008, USA

H. Davis · L. Rockwood

Department of Biology, George Mason University,

Fairfax, VA 22030, USA

T. Wood

New Century College, George Mason University, Fairfax, VA 22030, USA

Present Address:

H. Davis $(\bowtie)$

Department of Life Sciences, University of the West Indies, Mona Kingston 7, Kingston, Jamaica

e-mail: inornis@gmail.com that farmers, on average, could make an additional US $\$ 443.23$ and US\$1485.28 per ha. per year from fruit trees used as shade on high and low elevation coffee farms, respectively. With better marketing of fruit tree products and improved conditions of existing road networks to provide access to markets, shade coffee farms could significantly improve coffee farmer livelihoods and forest-like cover within the severely degraded agricultural areas within the Yallahs River watershed.

Keywords Agroforestry $\cdot$ Coffee $\cdot$ Shade trees · Fruit income $\cdot$ Blue Mountain · Jamaica

\section{Introduction}

Coffee is among the most traded commodities in the world, and coffee agroecosystems are some of the most prominent habitats in mid-elevation, speciesrich, forested areas of the tropics, including the Caribbean (Rice and Ward 1996; Rice 1999, 2003). Increasing economic opportunities for growing coffee in the tropics has led to a shift from traditional and sustainable coffee production under shade to unsustainable and habitat-degrading — but high-yieldingsun coffee agriculture (Beer et al. 1997; Philpott and Diestch 2003). Consequently, considerable research has been dedicated to the study of shade coffee agroecosystems as landscapes for the conservation of 
biodiversity such as migratory and resident birds (Robbins et al. 1992; Wunderle and Latta 1996; Greenberg et al. 1997) and the use of shade tree products for the economic benefit of coffee farmers in places such as Central and South America (Rice 2008, 2011) and Africa and Asia (Philpott et al. 2008; Elliott 2009). In addition, the role of shade trees in microclimate, soil and watershed management in coffee agroecosystems has been well documented (Nair 1989; Lin 2007).

A study by Rice (2008) showed that Guatemalan and Peruvian coffee farmers obtained 19 and $28 \%$ of the coffee agroecosystem value, respectively, from shade tree products that included fruits. Studies in Guatemala, Peru, Costa Rica, and Kenya found musaceous species (bananas and plantains) to be important in agroecosystems with much of the fruit value coming from these species (Albertin and Nair 2004; Elliott 2009; Rice 2011). In Costa Rica musaceous species were grown by $59 \%$ of coffee farmers and were among the top eight species reported, while 39 and $58 \%$ of farmers reported using these species in Guatemala and Peru, respectively. Thus, the contribution of shade tree products can be significant for coffee producers with small holdings $(\leq 2 \mathrm{ha})$ in a marketplace where coffee prices do not guarantee farmers the opportunity to recover farm operating costs (Bacon 2005). Additionally, since shade coffee agroecosystems focus on sustainability and economic benefit to farmers, they can be used as an important tool for habitat restoration efforts in areas where intensive coffee growing and other agricultural practices have resulted in severe habitat degradation (Barker and McGregor 1988).

Despite increased interest in the socioeconomics of sustainable coffee, studies that examine the economic value of shade tree products in coffee agroecosystems are lacking (Albertin and Nair 2004). To understand which shade tree species could benefit coffee farmers economically, this study evaluated the socioeconomic benefits of fruits derived from trees grown in coffee agroecosystems within the Yallahs River watershed in the southeastern Blue Mountains. Though several studies have acknowledged the importance of fruit trees and their contribution to the overall economics in agroforestry systems (Moguel and Toledo 1999; Philpott et al. 2007), what is needed is an assessment of the actual economic value shade derived products provide (Rice 2011). Such evidence may help further motivate farmer buy-in and lead to more sustainability within these agroecosystems. To date, no study has evaluated the economic benefits of fruit trees providing critical shade to coffee plants in the Caribbean.

\section{Study area and methods}

Study area

The Blue and John Crow Mountains are located within the parishes of Portland, St. Thomas, and St. Andrew and attain a maximum elevation of 2,290 m. The $810 \mathrm{~km}^{2}$ area comprises one third of the island's remaining closed broadleaf forest on hilly terrain and is largely influenced by the northeast trade winds that deliver the island's rainfall. The eastern sections of the Blue and John Crow Mountains National Park (BJCMNP) receive $1300-5000 \mathrm{~mm}$ of rain per year and have daily average temperatures that range from $27{ }^{\circ} \mathrm{C}$ in the lowlands to $13{ }^{\circ} \mathrm{C}$ and below at higher elevations (Asprey and Robbins 1953; Lack 1976; Downer and Sutton 1990). Forest types on Jamaica reflect a gradient of rainfall patterns, with dry limestone forest in the southern lowlands, wet limestone forest at middle elevations and very wet and montane forest at higher elevations in the Blue Mountains (Asprey and Robbins 1953; Lack 1976; Stattersfield et al. 1998). In many areas of the Blue Mountains, forest habitat below $1000 \mathrm{~m}$ elevation is severely denuded from years of slash-and-burn agriculture and numerous abandoned agricultural plantations, except for a few vegetated ravines that provide connectivity between montane and lowland areas (Barker and McGregor 1988).

The Blue Mountain area produces the worldfamous Blue Mountain coffee and harbors Jamaica's first national park, the Blue and John Crow Mountain National Park. Coffee producers interviewed for this study operate farms ranging between 300 and $1000 \mathrm{~m}$ elevation, form part of the Yallahs River watershed, and fall within the boundaries of the national park in the southeastern Blue Mountains where coffee covers a broken terrain on slopes that often exceed $50^{\circ}$ (Chai et al. 2009). Coffee producers shade their crop with a mix of native, timber and fruit tree species (Davis 2013) whose distribution was largely influenced by several abiotic and biotic factors and consideration of 
the steep mountainous terrain in this region (Willis 2015).

\section{Farmer surveys}

Assessments are based on a structured survey, along with a series of open-ended questions posed to coffee farmers during interviews in March and April 2010 (Davis 2013). The questionnaire was field tested via five interviews with farmers in 2009, which allowed for some modifications to create a questionnaire better suited for this study. The data gathered provide general characteristics and location of coffee farms, the amount and value of the coffee harvested, and the species, quantity, and value of all fruits harvested from trees providing shade in the coffee agroecosystem. The information presented and analyzed is based on the responses from a total of 40 interviewed farmers. Because of time and resource constraints, we did not conduct field visits to corroborate farmer response or inventory fruit tree species, but we visited a number of farms during the field test and have knowledge of farm phenology (Davis 2013) in both elevational areas, which gave us confidence that the information from the surveys indeed is representative of the farms.

\section{Data analysis}

Farm-level summaries were made using data from the questionnaires. These data include the size of the coffee farm holdings, the percent area within a farm that was planted with shade trees (mid-point of the range percent reported by farmers), the average gross coffee income per box of coffee berries, the quantity of fruits harvested from the shade layer, and the price received if fruits were sold. Coffee farmers provided the farm gate price whenever fruits were sold or taken to market (actual fruit income-income from direct fruit sales reported by farmers and farm gate prices), but where farmers did not sell fruits or were unsure of fruit values, these were computed using the farm gate price and quantity of fruits reported by farmers. When farm gate fruit value was known, they were reported as numbers, crates, dozens, pounds, or bunches-as was the case for musaceous species-sold. To make comparison of fruit value easy, these numbers, crates, or bunches were converted to estimates that were dozens or pounds using information from the coffee farmers or Morton (1987). The retail value of all fruits was determined from assessments of fruit prices during market visits in 2010 and these were used to compute the potential fruit income (income estimated from the quantity of fruits farmers reported each tree produces and market prices). These data on the type, quantity, value of fruits and coffee beans harvested from the coffee agroecosystem were used to compute coffee and fruit incomes for data analysis. Musaceous species were widely used for shade and income generation by farmers, and though these herbaceous species are not hardwood trees, for simplicity we treated them as "trees" in the data analysis (see mention of this in discussion section below). Some tropical fruit trees (e.g., Mangifera indica, Blighia sapida, Cocos nucifera) were not used by farmers or did not produce well above $800 \mathrm{~m}$ elevation. Temperate and subtropical fruit trees managed for shade (e.g., Citrus sp., Prunus sp., Annona cherimola) were found on farms above $800 \mathrm{~m}$ (Janick 2003). Therefore, each coffee farm was designated as high $(\geq 800 \mathrm{~m})$ or low $(\leq 799 \mathrm{~m})$ elevation, which determined the horticultural makeup of the farms. This designation also facilitated the determination of any elevation difference in the contribution of fruits from the shade trees to farmer incomes during data analysis. The number of fruit trees reported for each farm allowed for calculation of the Simpson's index of diversity for low and high elevation coffee farms. The software program Jump 9.0.2 (SAS Institute Inc. 2010) was used to perform t-tests for unequal variances to determine any significant difference in farm characteristics and coffee and fruit incomes at high and low elevations.

\section{Results}

Forty surveys were completed, with 27 from the lower elevation producers and 13 from those above 800 meters. Combining information from all surveys, we found that farmers reported growing a total of 24 species of tropical, subtropical, and temperate fruit trees as part of the shade canopy (Table 1). Mangoes (Mangifera indica), bananas (Musa sp.), plantains (Musa sp.), oranges (Citrus sp.), grapefruits (Citrus sp.), lemons (Citrus sp.), peach (Prunus sp.), and cherimoya (Annona cherimola)—eight trees with greater than $1 \%$ farm presence-accounted for more than $97 \%$ of all fruit trees managed on high elevation 
Table 1 Fruit tree species, the percentage of all fruit trees reported by elevation, the percentage of farmers reporting each species, and the total fruit value (based on AVERAGE fruit volume provided from all farmers combined) each tree species contributed to reported farmer income in the Yallahs River watershed, southeastern Blue Mountains, Jamaica W.I., 2010

\begin{tabular}{|c|c|c|c|c|c|c|c|}
\hline \multirow[t]{2}{*}{ Scientific name } & \multirow[t]{2}{*}{ Local name } & \multicolumn{2}{|c|}{$\%$ of fruit trees reported by farmers } & \multicolumn{2}{|c|}{$\begin{array}{l}\% \text { of farmers reporting each } \\
\text { species }\end{array}$} & \multicolumn{2}{|c|}{$\begin{array}{l}\text { Total Fruit value } \\
\text { (US\$)/ha/year }\end{array}$} \\
\hline & & $\begin{array}{l}\operatorname{High}^{\mathrm{a}} \\
(\mathrm{N}=2920)\end{array}$ & $\begin{array}{l}\text { Low }^{\mathrm{b}} \\
(\mathrm{N}=2447)\end{array}$ & $\begin{array}{l}\operatorname{High}^{\mathrm{a}} \\
(\mathrm{N}=13)\end{array}$ & $\begin{array}{l}\text { Low }^{\mathrm{b}} \\
(\mathrm{N}=27)\end{array}$ & $\operatorname{High}^{\mathrm{a}}$ & Low $^{b}$ \\
\hline Mangifera indica & Mango & 1.23 & 8.50 & 38.46 & 81.48 & 109.02 & 3796.90 \\
\hline Musa sp. & Banana & 85.27 & 70.25 & 38.46 & 44.44 & 552.35 & 2015.60 \\
\hline Persea americana & Avocado & 0.34 & 2.13 & 23.08 & 33.33 & 581.42 & 1988.95 \\
\hline Blighia sapida & Ackee & $\mathrm{n} / \mathrm{a}$ & 5.97 & $\mathrm{n} / \mathrm{a}$ & 48.15 & $\mathrm{n} / \mathrm{a}$ & 655.83 \\
\hline $\begin{array}{l}\text { Syzygium } \\
\text { samarangense }\end{array}$ & $\begin{array}{l}\text { Otaheite } \\
\text { apple }\end{array}$ & 0.38 & 1.23 & 15.38 & 25.93 & $\mathrm{n} / \mathrm{a}$ & 296.77 \\
\hline Musa sp. & Plantains & 3.94 & 1.84 & 15.38 & 18.52 & 392.46 & 127.17 \\
\hline Citrus sp. & Orange & 1.16 & 2.41 & 38.46 & 44.44 & 109.02 & 239.66 \\
\hline Citrus sp. & Grapefruit & 1.44 & 2.00 & 46.15 & 44.44 & 101.75 & 130.13 \\
\hline Artocarpus altilis & Breadfruit & $\mathrm{n} / \mathrm{a}$ & 1.51 & $\mathrm{n} / \mathrm{a}$ & 22.22 & $\mathrm{n} / \mathrm{a}$ & 97.60 \\
\hline Chrysophyllum cainito & Star Apple & $\mathrm{n} / \mathrm{a}$ & 0.25 & $\mathrm{n} / \mathrm{a}$ & 7.41 & $\mathrm{n} / \mathrm{a}$ & 58.14 \\
\hline Annona muricata & Soursop & 0.03 & 2.17 & 15.38 & 37.04 & $\mathrm{n} / \mathrm{a}$ & 68.80 \\
\hline Pimenta dioica & Pimento & 0.41 & $\mathrm{n} / \mathrm{a}$ & 7.69 & $\mathrm{n} / \mathrm{a}$ & 58.14 & $\mathrm{n} / \mathrm{a}$ \\
\hline Citrus sp. & Lemons & 1.23 & $\mathrm{n} / \mathrm{a}$ & 38.46 & $\mathrm{n} / \mathrm{a}$ & 40.70 & $\mathrm{n} / \mathrm{a}$ \\
\hline $\begin{array}{l}\text { Artocarpus } \\
\text { heterophyllus }\end{array}$ & Jackfruit & 0.10 & 0.29 & 7.69 & 14.81 & $\mathrm{n} / \mathrm{a}$ & 14.54 \\
\hline Prunus sp. & Peach & 2.29 & $\mathrm{n} / \mathrm{a}$ & 30.77 & $\mathrm{n} / \mathrm{a}$ & 16.28 & $\mathrm{n} / \mathrm{a}$ \\
\hline Psidium guajava & Guava & 0.75 & 0.25 & 15.38 & 3.70 & 2.91 & $\mathrm{n} / \mathrm{a}$ \\
\hline Theobroma cacao & Cacao & $\mathrm{n} / \mathrm{a}$ & 0.82 & $\mathrm{n} / \mathrm{a}$ & 3.70 & $\mathrm{n} / \mathrm{a}$ & $\mathrm{n} / \mathrm{a}$ \\
\hline Annona cherimola & Cherimoya & 1.30 & $\mathrm{n} / \mathrm{a}$ & 30.77 & $\mathrm{n} / \mathrm{a}$ & $\mathrm{n} / \mathrm{a}$ & $\mathrm{n} / \mathrm{a}$ \\
\hline Cocos nucifera & Coconut & $\mathrm{n} / \mathrm{a}$ & 0.04 & $\mathrm{n} / \mathrm{a}$ & 3.70 & $\mathrm{n} / \mathrm{a}$ & $\mathrm{n} / \mathrm{a}$ \\
\hline Spondias dulcis & June plum & $\mathrm{n} / \mathrm{a}$ & 0.12 & $\mathrm{n} / \mathrm{a}$ & 3.70 & $\mathrm{n} / \mathrm{a}$ & $\mathrm{n} / \mathrm{a}$ \\
\hline Citrus sp. & Lime & $\mathrm{n} / \mathrm{a}$ & 0.16 & $\mathrm{n} / \mathrm{a}$ & 3.70 & $\mathrm{n} / \mathrm{a}$ & $\mathrm{n} / \mathrm{a}$ \\
\hline Myristica fragrans & Nutmeg & $\mathrm{n} / \mathrm{a}$ & 0.04 & $\mathrm{n} / \mathrm{a}$ & 3.70 & $\mathrm{n} / \mathrm{a}$ & $\mathrm{n} / \mathrm{a}$ \\
\hline Carica papaya & Papaya & 0.10 & $\mathrm{n} / \mathrm{a}$ & 7.69 & $\mathrm{n} / \mathrm{a}$ & $\mathrm{n} / \mathrm{a}$ & $\mathrm{n} / \mathrm{a}$ \\
\hline Citrus sp. & Tangerine & $\mathrm{n} / \mathrm{a}$ & 0.04 & 7.69 & $\mathrm{n} / \mathrm{a}$ & $\mathrm{n} / \mathrm{a}$ & $\mathrm{n} / \mathrm{a}$ \\
\hline
\end{tabular}

${ }^{\mathrm{a}}$ Elevation $\geq 800 \mathrm{~m}$

${ }^{\mathrm{b}}$ Elevation $\leq 799 \mathrm{~m}$

farms in this study. Similarly, mangoes, bananas, avocado (Persea Americana), ackee (Blighia sapida), otaheite apple (Syzygium samarangense), plantain, orange, grapefruit, breadfruit (Artocarpus altilis), and soursop (Annona muricata) - ten trees with greater than $1 \%$ farm presence-accounted for more than $98 \%$ of all fruit trees managed on low elevation farms. Bananas, constituting 85.27 and $70.25 \%$ of all trees at high and low elevations, respectively, had the largest on-farm presence of all fruit trees reported by farmers.
Ackee, breadfruit, star apple (Chrysophyllum cainiypicalto), and cacao (Theobroma cacao) were typically planted for shade on coffee farms at lower elevations. Higher-elevation coffee farmers typically used cherimoya, peach, and lemons as part of the shade canopy.

Thirty four percent (average) of coffee farmers reported using one or more of the eight fruit trees for shade on high elevation farms, while $40 \%$ (average) reported using one or more of the ten fruit trees for shade on low elevation farms (Table 1). Although 
many coffee farmers reported using species such as Jackfruit (Artocarpus heterophyllus) and guava (Psidium guajava), they had less than $1 \%$ on-farm presence (Table 1).

Fruits from six trees-mango, banana, avocado, plantain, orange, and grapefruit-with more than US $\$ 100$ value, contributed total US $\$ 1846.02$ to fruit income on high elevation farms. This value represents more than $90 \%$ of the total fruit income reported for these farms. Although avocado had less than $1 \%$ onfarm presence, more than $20 \%$ of farmers reported using it for shade on their farms and fruit sales contributed approximately $30 \%$ to the total fruit income for high elevation farms. But peaches, which had more than $2 \%$ on-farm presence and reported by more than $30 \%$ of farmers, only contributed US\$16.28 to total fruit income.

Mango, banana, avocado, ackee, otaheite apple, plantain, orange, and grapefruit—eight fruit trees with more than US $\$ 100$ value-contributed US $\$ 9251.01$ to fruit income on low elevation farms (Table 1). This is more than $97 \%$ of the total fruit income of these farmers. Avocados (US\$581.42) and Mangoes (US\$3796.90) contributed the most to total fruit incomes on high and low farms, respectively. While bananas, which had the largest on-farm presence of all fruit trees-regardless of elevation-contributed 28 and $21 \%$ to the total fruit incomes of farmers at high and low elevations, respectively.

All farms received the standard US $\$ 39 /$ box for ripe coffee cherries during 2009-2010 coffee harvest. We found no significant difference between high or low elevation coffee farm characteristics-farm size, number of boxes of coffee per ha. per year, percentage of farm with shade trees, number of fruit tree types, number of fruit trees per ha. - and farmers at high and low elevations derived no difference in income from the sale of ripe coffee berries in the Yallahs River watershed (Table 2). Although not significantly different, high elevation farms were on average larger than those at lower-elevations (0.30-30.35 ha. compared to 0.20-9.71 ha.), and while some higherelevation farmers did not use fruit trees as part of the shade canopy, all lower-elevation farmers planted fruit trees for shade (range in the number of fruit trees per ha. was $0-6$ and $0.17-8$ at high and low elevations, respectively).

Farmers at low elevations, however, reported significantly greater actual and potential fruit incomes and had twice the diversity of fruit trees as coffee farmers at higher elevations (Table 2). Farmer's potential fruit income was also greater than actual fruit income at low compared to high elevations. The percentage of income derived from fruits was also twice that for farmers at low elevations.

Other than fruit trees, coffee farmers also reported using Cedrela odorata, Grevillea robusta, Hibiscus elatus, Nectandra sp., and Pinus caribbea on high elevation and Cordia alliodora, Cordia gerscanthusa, Ficus sp., Gliricidia sepium, elatus, Leucaena leucocephala, Samanea saman, Simaruba glauca, and Spathodia companulata on low elevation farms as part of the shade canopy. But, the data were sparse and insufficient for any rigorous analysis.

\section{Discussion}

This study demonstrates the use, importance, and economic value of fruit trees grown as shade in coffee agroecosystems within the Yallahs River watershed in Jamaica. Although coffee farmers used 24 fruit tree species as part of the entire shade complement, the fruits of which were harvested for personal use or sold to supplement incomes, their contribution to fruit incomes varied according to high or low elevation. A possible reason for this difference may be due to the use of fewer fruit trees by coffee farmers to provide shade for coffee plants at higher elevations, because it is believed that the ever-present mist cover provides "shade" enough for coffee shrubs, and planting more trees will increase leaf spot symptoms and reduce yields (Robinson 2006; Kellermann et al. 2008; Johnson et al. 2009; Willis 2015). Musaceous species played an important role in the southeastern Blue Mountain coffee systems, with bananas having an even spread at high and low elevations. The use of these large, herbaceous, and succulent plants that are often mistakenly referred to as "trees" (Morton 1987) for shade is considered a necessity to protect young coffee plants from direct sun, guard against drought, and ensure income and food production for the first 3-4 years in coffee agriculture (Albertin and Nair 2004; Robinson 2006). Similar to results from research in Central America, Africa and Asia, the results from this study also point to their importance in Blue Mountain coffee agriculture where these species 
Table 2 Comparison of coffee farm characteristics and coffee and fruit incomes at high and low elevations in the Yallahs River Watershed, South-eastern Blue Mountains, Jamaica W.I. In parentheses are the standard errors and sample size where applicable

\begin{tabular}{|c|c|c|c|}
\hline Variable & High & Low & $t$ test results \\
\hline Number of farmers surveyed & 13 & 27 & $\mathrm{n} / \mathrm{a}$ \\
\hline Average Farm size (ha) & $3.14(1.40)(n=13)$ & $2.02(0.97)(n=27)$ & ns \\
\hline $\begin{array}{l}\text { Average Number of boxes of coffee/ha/ } \\
\text { year }^{\mathrm{a}}\end{array}$ & $76.88(9.41)(n=13)$ & $76.09(10.13)(n=24)$ & ns \\
\hline$\%$ of farm with shade trees & $47.3(6.58)(n=13)$ & $54.07(4.57)(n=27)$ & ns \\
\hline Number of fruit tree species & $3.76(0.55)(n=13)$ & $4.48(0.38)(n=27)$ & ns \\
\hline Average Number of fruit trees/ha & $2.13(0.52)(n=13)$ & $2.01(0.37)(n=27)$ & ns \\
\hline Simpson's index of diversity $(1-D)^{b}$ & 0.27 & 0.49 & $\mathrm{n} / \mathrm{a}$ \\
\hline Coffee income (US\$/ha/year) & $2984.64(365.31)(n=13)$ & $2953.88(393.09)(n=24)$ & ns \\
\hline Actual fruit income (US\$/ha/year) & $151.08(65.31)(n=13)$ & $351.49(84.10)(n=27)$ & $\begin{aligned} t= & -1.54(\text { d.f. }=37.37) \\
P & =0.0181\end{aligned}$ \\
\hline Potential fruit income (US\$/ha/year) & $443.23(217.79)(n=13)$ & $1485.28(360.80)(n=27)$ & $\begin{array}{c}t=-1.91(\text { d.f. }=37.58) \\
P=0.0676\end{array}$ \\
\hline Fruit value as $\%$ of gross coffee income & $7.5(n=8)$ & $14.0(n=20)$ & $\mathrm{n} / \mathrm{a}$ \\
\hline
\end{tabular}

${ }^{\mathrm{a}} \mathrm{A}$ standard field box in Jamaica is $35.56 \times 48.26 \times 24.77 \mathrm{~cm}$ or about $27.2 \mathrm{~kg}$ of ripe coffee cherries (Johnson et al. 2010)

${ }^{\mathrm{b}}$ Diversity of fruit trees

remained economically important after coffee shrubs reached maturity and began berry production.

Low-elevation coffee farmers managed more of each fruit tree type as part of the shade canopy with mango, avocado, ackee, and otaheite apple-reported mostly by low elevation farmers-contributing US\$6738.45 to total fruit income, mango alone accounting for more than $55 \%$ of this total (Table 1). While some farmers at higher elevations practiced highly intensive coffee husbandry, farms at lower elevations were rustic - the producers managing a more diverse complement of fruit trees as part of the shade canopy (Davis 2013). This difference in coffee husbandry allowed lower-elevation coffee farmers to realize significantly greater fruit incomes (Table 2). Although no statistical comparison was made between actual fruit income and potential fruit income within or between elevation zones, it is clear that coffee farmers can net more income if they had better opportunities to take fruits from the shade component to market (Table 2).

This also speaks to the importance of geography in Blue Mountain coffee agriculture. Our results suggest that on larger farms at higher-elevation-some as large as 30 ha.--farmers used fewer fruit trees as part of the shade canopy because of dense fog and cloud cover typical at higher-elevations and their desire to minimize the effects of American leaf spot disease and increase coffee yields (Robinson 2006). This largely contributed to the lower fruit values observed for these farmers in this study (Table 1). Additionally, the smaller number of high elevation coffee producers participating in the surveys made it difficult to detect patterns in the data and resulted in the low fruit values observed.

Blue Mountain coffees' premium-price and high market value offer producers stability and incentives in the global market place (Kaplinsky 2006). But, this dynamic is not fixed or consistent, since coffee prices have a tendency to fluctuate from year to year (Collinder 2010, 2011; Brown 2015). So, having alternative income generated from the sale of fruits could provide farmers with an additional buffer during years when income from coffee is low. Moreover, Willis (2015) found that coffee farmers planted shade trees from which they could harvest fruit products as a food security mechanism due to inflated cost of staple food items in the Blue Mountains.

That the number of non-fruit tree species reported by high elevation coffee farmers was similar to the number of fruit trees planted by these farmers is not surprising, since these farmers typically used fewer 
trees in Blue Mountain coffee agriculture. Based on the types of non-fruit tree species reported, it appears that - other than for shade-higher-elevation farmers used these trees for their potential as lumber, the realized value from which can be quite large (Rice 2008). But we obtained little or no data about these values from farmers in this study. Also, the list of nonfruit tree species reported by these producers was incomplete, missing obvious trees such as Eucalyptus elatus and Alchornia latifolia, which are prominent features on higher-elevation farms (Kellermann et al. 2008; Davis 2013).

The results presented here suggest that Blue Mountain coffee farmers overlook fortuitous opportunities for additional economic gain from the fruit trees they use as shade on coffee farms (Table 2). It is possible that farmers view the use and value of fruit trees for their environmental (shade, soil conservation, and microclimate regulation) and personal benefits (Robinson 2006; Willis 2015), and not necessarily for their income generating potential. Willis (2015) suggests that, beyond the farmers' general indifference towards adopting what is clearly economically and ecologically better agricultural practices in the Blue Mountain coffee agriculture, they see and experience the tangible results of environmental degradation through their struggles with landslides, soil erosion, lost soil fertility and the mounting economic costs to deal with these problems.

It is also worth mentioning access to markets as a factor in farmers' not taking advantage of the potential income from the fruits derived from the shade trees. Despite an increase in the number and total length of roads paved in Jamaica in recent decades (Easterly and Serven 2003), hindrances to the farmers' ability to market shade tree products include the lack of transport and the maintenance of roads that are often washed out by heavy rainfall or impacted by landslides in this rugged terrain (Henry 1997; Thompson 2009; Henry 2015). As a result, fruit products from the shade canopy are often not taken to market but are sold opportunistically at some negotiated farm-gate price (Thompson 2009). Robinson (2006) alluded to this when she reported that Blue Mountain coffee farmers she interviewed demonstrated enthusiasm for and a general recognition of the need to implement conservation and alternative measures to ensure environmental protection and secure future profitability and sustainability in the industry.

\section{Conclusion}

This study demonstrates that Blue Mountain coffee farmers can reap additional economic rewards from fruit trees already being used for shade on coffee farms. These economic benefits could be realized with management and marketing of these products and improved condition of existing road networks. The actual and potential benefits are not uniform across the elevational gradient, however, and will depend on the type of horticulture best suited to the climates in the Blue Mountains. But the current political and economic structure within Blue Mountain coffee industry must change and farmers must choose or be advised on which tropical, subtropical or temperate fruit trees will be most productive in the climatic conditions on their coffee farms. The results obtained in this study were informative, but could have benefitted from field visits to inventory fruit trees used as shade.

Further, the Yallahs River watershed, and by extension the BJCMNP, suffers from widespread forest cover loss due primarily to unsustainable agricultural practices that clear and remove forest through slash-and-burn agriculture. Information is needed on the most appropriate trees to employ in any forest rehabilitation programs that would bring economic and environmental benefits to coffee farmers and the area, respectively. Several candidate fruit tree species (e.g., Mangifera indica and Persea Americana) emerged from this study that could be useful in such reforestation efforts and at the same time bring economic benefits to coffee farmers. Additionally, long term research is needed to better understand how fruits and other types of products, such as timber, from the shade coffee systems contribute to the farmer and overall community incomes during periods of robust or weak revenue streams.

Acknowledgements This research was made possible by a Doctoral Fellowship in Conservation Science offered jointly by the Department of Environmental Science and Public Policy, George Mason University and the Smithsonian Institution's National Zoological Park (NZP), a James Bond Endowment Trust grant provided to P.P. Marra and H. Davis by the Smithsonian Institution, and a grant to P.P. Marra and H. Davis from the Smithsonian Migratory Bird Center Coffee Fund. Essential assistance in the field was provided by J. Carson. We would like to say a special thanks to Mr. John Fletcher, Mr. Noel Levy, and Dr. Peter Fletcher for kindly allowing me to use the Ramble Hill Estate house for accommodation during this study. 
To the many coffee farmers that willingly participated in the farm survey we say many thanks. Finally, this research was conducted under permits from the National Environment and Planning Agency of Jamaica.

Open Access This article is distributed under the terms of the Creative Commons Attribution 4.0 International License (http:// creativecommons.org/licenses/by/4.0/), which permits unrestricted use, distribution, and reproduction in any medium, provided you give appropriate credit to the original author(s) and the source, provide a link to the Creative Commons license, and indicate if changes were made.

\section{References}

Albertin A, Nair PKR (2004) Farmers' perspectives on the role of shade trees in coffee production systems: an assessment from the Nicoya Peninsula, Costa Rica. Hum Ecol 32:443-463

Asprey GF, Robbins RG (1953) The vegetation of Jamaica. Ecol Monogr 23:359-412

Bacon C (2005) Confronting the coffee crisis: can fair trade, organic, and specialty coffees reduce small-scale farmer vulnerability in northern Nicaragua? World Dev 33:497-511

Barker D, McGregor DFM (1988) Land degradation in the Yallahs basin, Jamaica: historical notes and contemporary observations. Geography 73:116-124

Beer J, Muschler R, Kass D, Somarriba E (1997) Shade management in Coffee and Cacao plantations. Agrofor Syst 38:139-164

Brown I (2015) Coffee farmers back in the fields as prices soar. Jam. Obs. Ltd.

Chai SL, Tanner E, McLaren K (2009) High rates of forest clearance and fragmentation pre- and post-National park establishment: the case of a Jamaican montane rainforest. Biol Conserv 142:2484-2492

Collinder A (2010) Coffee farmers to lose millions. Jam. Glean. Online

Collinder A (2011) Coffee sales improve. Jam. Glean. Online

Davis HA (2013) The Biological and Economic Benefits of Shade Coffee Plantations in the Blue Mountain, Jamaica WI. Ph.D., George Mason University

Downer A, Sutton R (1990) Birds of Jamaica: a photographic field guide. Cambridge University Press, Cambridge

Easterly W, Serven L (2003) The limits of stabilization: infrastructure, public deficits and growth in Latin America. World Bank Publications, Washington

Elliott LC (2009) Farmers' perceptions about the utilities of trees associated with coffee farms in central province, Kenya. University of Toronto, Toronto

Greenberg R, Bichier P, Angon AC, Reitsma R (1997) Bird populations in shade and sun coffee plantations in central Guatemala. Conserv Biol 11:448-459

Henry M (1997) Agriculture in Jamaica 1991-1995 and Beyond. Inter-American Institute for Coorporation on Agriculture, Trinidad and Tobago
Henry P (2015) Buchanan takes heat for poor roads, infrastructure. Jam. Obs. Ltd.

Janick J (2003) “Horticulture.” Encyclopedia of food and culture. In: Encyclopedia.com. http://www.encyclopedia. com/doc/1G2-3403400325.html. Accessed 9 Mar 2012

Johnson M, Levy NJ, Kellermann JL, Robinson DE (2009) Effects of shade and bird exclusion on arthropods and leaf damage on coffee farms in Jamaica's Blue Mountains. Agrofor Syst 76:139-148

Johnson MD, Kellermann JL, Stercho AM (2010) Pest reduction services by birds in shade and sun coffee in Jamaica. Anim Conserv 13:140-147

Kaplinsky R (2006) Revisiting the revisited terms of trade: will China make a difference? World Dev 34:981-995

Kellermann JL, Johnson MD, Stercho AMYM, Hackett SC (2008) Ecological and economic services provided by birds on Jamaican Blue Mountain coffee farms. Conserv Biol 22:1177-1185

Lack D (1976) Island biology: illustrated by the land birds of Jamaica. University of California Press Berkeley, CA

Lin BB (2007) Agroforestry management as an adaptive strategy against potential microclimate extremes in coffee agriculture. Agric For Meteorol 144:85-94

Moguel P, Toledo VM (1999) Biodiversity conservation in traditional coffee systems of Mexico. Conserv Biol 13:11-21

Morton JF (1987) Fruits of warm climates. JF Morton, Miami

Nair PKR (ed) (1989) Agroforestry systems in the tropics. Kluwer Academic Publishers, Dordrecht

Philpott SM, Diestch T (2003) Coffee and conservation: a global context and the value of farmer involvement. Conserv Biol 17:1844-1846

Philpott SM, Bichier P, Rice R, Greenberg R (2007) Fieldtesting ecological and economic benefits of coffee certification programs. Conserv Biol 21:975-985

Philpott SM, Bichier P, Rice RA, Greenberg R (2008) Biodiversity conservation, yield, and alternative products in coffee agroecosystems in Sumatra, Indonesia. Biodivers Conserv 17:1805-1820

Rice R (1999) A place unbecoming: the coffee farm of Latin America. Geogr Rev 89:554-579

Rice R (2003) Coffee production in a time of crisis: social and environmental connections. SAIS Rev 23:221-245

Rice R (2008) Agricultural intensification within agroforestry: the case of coffee and wood products. Agric Ecosyst Environ 128:212-218

Rice R (2011) Fruits from shade trees in coffee: how important are they? Agrofor Syst 83:41-49

Rice R, Ward JR (1996) Coffee, conservation, and commerce in the western hemisphere: how individuals and institutions can promote ecologically sound farming and forest management in northern Latin America. Smithsonian Migratory Bird Center, Washington

Robbins CS, Dowell BA, Dawson DK et al (1992) Comparison of Neotropical migrant landbird population in tropical forests, isolated fragments, and agricultural habitats. In: Hagan JM III, Johnson MD (eds) Ecology and conservation of Neotropical migrant landbirds. Smithsonian Institution Press, Washington, pp 207-220 
Robinson HA (2006) BJCMNP "conservation coffee project": economic analysis report prepared for Jamaica Conservation and Development Trust

Stattersfield AJ, Crosby MJ, Long A, Wege D (1998) Endemic bird areas of the world: priorities for biodiversity conservation

Thompson K (2009) Bad roads threaten farmers' livelihood in St Thomas Eastern. Jam. Obs. Ltd.
Willis WC (2015) The political ecology of shade coffee: perspectives from Jamaican Blue Mountain farmers. Humboldt State University, Arcata

Wunderle JM, Latta SC (1996) Avian abundance in sun and shade coffee plantations and remnant pine forest in the Cordillera Central, Dominican Republic. Ornitol Neotropical 7:19-34 